Check for updates

Cite this: RSC Adv., 2017, 7, 30142

\title{
Graphene-decorated silica stabilized stearic acid as a thermal energy storage material $\dagger$
}

\begin{abstract}
Chuanchang Li, (D)* Baoshan Xie and Jian Chen*
Novel thermal energy storage materials were synthesized from graphene-decorated silica (SG) and stearic acid (SA) by vacuum impregnation method. Three kinds of $S G\left(S_{1}, S_{5}\right.$, and $\left.S_{G} G_{10}\right)$ were prepared by decorating silica with different contents of graphene and were then used to stabilize SA to prepare SA/ $\mathrm{SG}_{1}, \mathrm{SA} / \mathrm{SG}_{5}$, and $\mathrm{SA} / \mathrm{SG}_{10}$ composites. The structures and thermal energy storage performances of the SA/SG composites were investigated. It is of interest that the thermal energy storage behaviors of the SA/ SG composites were dramatically changed with different contents of graphene, presenting more than one endothermal or exothermal peak in the differential scanning calorimetry (DSC) curves while pure SA had only one. The $\mathrm{SA}$ in $\mathrm{SA} / \mathrm{SG}_{1}$ and $\mathrm{SA} / \mathrm{SG}_{5}$ showed higher crystallinity $\left(F_{\mathrm{C}}, 84.44 \%\right.$ and $\left.84.39 \%\right)$ and greater effective energy storage per unit mass $\left(E_{\mathrm{ef}} \sim 150 \mathrm{~J} \mathrm{~g}^{-1}\right)$ than that of $\mathrm{SA}$ in $\mathrm{SA} / \mathrm{SG}_{10}$. These thermal energy storage behaviors and properties were revealed to be related to the pore structures of the SG. The thermal stability of the SA/SG composites was analyzed by a thermogravimetric analyzer (TGA), and the SA/SG composites have good thermal stability. Addition of graphene was beneficial to the enhancement in thermal conductivity of the SA/SG composite, which could reach $0.90 \mathrm{~W} \mathrm{~m}^{-1} \mathrm{~K}^{-1}$, $1.05 \mathrm{~W} \mathrm{~m}^{-1} \mathrm{~K}^{-1}$, and $1.12 \mathrm{~W} \mathrm{~m}^{-1} \mathrm{~K}^{-1}$ for $\mathrm{SA} / \mathrm{SG}_{1}, \mathrm{SA} / \mathrm{SG}_{5}$, and $\mathrm{SA} / \mathrm{SG}_{10}$, respectively; and were $246 \%$, $304 \%$, and $331 \%$ higher than pure SA, respectively. SA/SG 5 has potential for application in thermal energy storage, especially in thermal gradients due to it having both high $E_{\text {ef }}$ and thermal conductivity.
\end{abstract}

Received 8th May 2017

Accepted 4th June 2017

DOI: 10.1039/c7ra05204a

rsc.li/rsc-advances with supporting matrix (e.g., carbon materials, metal or their oxides, porous structure materials, nanomaterials, etc.) into form-stable composite PCMs is the most promising practical method to overcome these problems. ${ }^{6,11,14-21}$

Silica-based materials has been used as supporting matrix due to it can make liquid PCMs easy to handle and protect PCMs from harmful interactions with the surrounding materials and environment during the phase change process. ${ }^{22}$ Fang et al. successfully used silicon dioxide or silica shell to stabilize $n$ hexadecane, ${ }^{23}$ lauric acid, ${ }^{24}$ and octadecane, ${ }^{11}$ respectively, and the thermal storage capacities of the prepared composite PCMs were $100-230 \mathrm{~J} \mathrm{~g}^{-1}$. Chung et $a .^{25}$ successfully impregnated octadecane and BioPCM into the pore of micronized silica and the prepared composite PCMs also had considerable thermal storage capacities (86.07-108.1 $\left.\mathrm{J} \mathrm{g}^{-1}\right)$. The octadecane and BioPCM molecules were held easily into the pore of micronized silica by these physical interactions and thus leakage of the melted PCM from the porous was prevented. Wang et al. ${ }^{26}$ skillfully impregnated stearic acid into the silica fume matrix and its thermal storage capacity was $84.47 \mathrm{~J} \mathrm{~g}^{-1}$ while the maximum percentage of stearic acid in the composite was 46 wt\%. Jeong et al. ${ }^{27}$ also utilized the silica fume to support hexadecane, octadecane, and paraffin, respectively. The thermal storage capacities of the prepared composite PCMs were 50-90 J $\mathrm{g}^{-1}$ and they were useful for applying to building materials. Min et $a l^{22}$ for the first time used the radial mesoporous silica to
Key Laboratory of Renewable Energy Electric-Technology of Hunan Province, School of Energy and Power Engineering, Changsha University of Science and Technology, Changsha 410114, China. E-mail: chuanchangli@csust.edu.cn; chenjian_513@126. com; Fax: +86-0731-85258409; Tel: +86-0731-85258409

$\dagger$ Electronic supplementary information (ESI) available. See DOI: 10.1039/c7ra05204a 
support polyethylene glycol, and their thermal storage capacities were $60-120 \mathrm{~J} \mathrm{~g}^{-1}$ with different contents of PEG. Song et al. ${ }^{28}$ used the silica shell microencapsulated caprice-stearic acid with a thermal storage capacity of $91.48 \mathrm{~J} \mathrm{~g}^{-1}$ while the encapsulation ratio was $56.7 \mathrm{wt} \%$, and prepared composite PCMs showed good thermal reliability. Also, the silica shell encapsulated phase

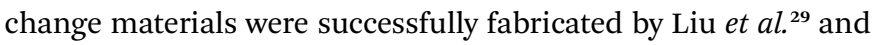
the thermal storage capacities were range from $30-110 \mathrm{~J} \mathrm{~g}^{-1}$ with different encapsulation ratios. These above mentioned silicabased composite PCMs had considerable thermal storage capacities. Therefore, the silica is a promising supporting matrix to stabilize PCMs and prevent the melted PCMs leakage. Also the thermal conductivities of PCMs were improved to $0.6-0.8 \mathrm{~W} \mathrm{~m}^{-1}$ $\mathrm{K}^{-1}$ by silica. ${ }^{29,30} \mathrm{As}$ an advanced heat transfer organic materials with excellent thermal conductivities, the PCMs preferably has a thermal conductivity above $1 \mathrm{~W} \mathrm{~m}^{-1} \mathrm{~K}^{-1}$, which broadens its wide application for thermal energy storage. ${ }^{31,32}$

In this paper, in order to enhance the thermal properties of silica-based composite PCMs, we firstly decorated silica by graphene, which has attracted a great deal of attention in recent years because of its high thermal conductivity. ${ }^{33}$ Then we synthesized novel composite PCMs (SA/SG) from graphenedecorated silica (SG) and stearic acid (SA) by a simple blending and impregnation process. The structures and thermal energy storage performances of the SA/SG composites were investigated. It is of interest that the thermal energy storage behaviors of SA/SG composites were dramatically changed along with different contents of graphene, presenting more than one endothermal or exothermal peaks in the DSC curves while pure SA only one of that. The thermal conductivity of the SA/SG reached $1.12 \mathrm{~W} \mathrm{~m}^{-1} \mathrm{~K}^{-1}$, which was $331 \%$ higher than that of pure SA.

\section{Experimental}

\subsection{Materials}

Silica sol $\left(\mathrm{SiO}_{2}, 30 \mathrm{wt} \%\right)$ was supplied by Research Institute of Tsinghua University In Shenzhen, China. Graphite was purchased from Qingdao Graphite Co., Ltd., China. $\mathrm{KMnO}_{4}$, $\mathrm{H}_{2} \mathrm{O}_{2}$ and $\mathrm{NaNO}_{3}$ were purchased from Xilong Chemical Co., Ltd. $\mathrm{H}_{2} \mathrm{SO}_{4}$ and $\mathrm{HCl}$ was purchased from Research Institute Of Chemical Industry In Zhuzhou. (3-Aminopropyl)-triethoxysilane (APTS) was purchased from Nanjing Compton Shuguang Organosilicon Chemical Co., Ltd. (China). Stearic acid (SA, $\left.\mathrm{CH}_{3}\left(\mathrm{CH}_{2}\right)_{16} \mathrm{COOH}\right)$ was supplied by Tianjin Hengxing Chemical Reagent Co., Ltd., China.

\subsection{Preparation procedures of the composites}

Typical procedures were depicted in Fig. 1, including preparation of the SG and the SA/SG composites.

2.2.1. Preparation of the SG. The SG were prepared from the GO and SN. The GO dispersion was prepared by simple sonication of graphite oxide that was obtained from natural graphite using a modified Hummers' method. ${ }^{34,35}$ Graphite $(2.5$ g) and $\mathrm{NaNO}_{3}(1.25 \mathrm{~g})$ were mixed with a $95 \% \mathrm{H}_{2} \mathrm{SO}_{4}(60 \mathrm{~mL})$ in a $250 \mathrm{~mL}$ flask. The mixture was stirred for $30 \mathrm{~min}$ in an ice bath. Under vigorous stirring, $7.5 \mathrm{~g}$ of $\mathrm{KMnO}_{4}$ was added to the suspension. The rate of addition was controlled to keep the reaction temperature lower than $20^{\circ} \mathrm{C}$. The ice bath was then removed, and the mixture was stirred at $35^{\circ} \mathrm{C}$ for $5 \mathrm{~h}$. Afterward, $150 \mathrm{~mL}$ of deionized $\mathrm{H}_{2} \mathrm{O}$ was slowly added to the mixture still under vigorous agitation. The reaction temperature was observed to rapidly increase to $98{ }^{\circ} \mathrm{C}$. The diluted suspension was stirred for $12 \mathrm{~h}$. Then, $25 \mathrm{~mL}$ of $30 \% \mathrm{H}_{2} \mathrm{O}_{2}$ was added to the mixture. To purify, the mixture was washed with $5 \%$ of $\mathrm{HCl}$ and then with deionized $\mathrm{H}_{2} \mathrm{O}$ for several times to obtain the graphite oxide sample. The final GO dispersion was prepared by diluted and sonication of graphite oxide, and concentration of GO is $1 \mathrm{mg} \mathrm{mL}^{-1}$.

The SN was prepared by silanizing of $\mathrm{SiO}_{2}$. Silanized of $\mathrm{SiO}_{2}$ with the APTS coupling agent: the silica sol $(300 \mathrm{~g})$ was mixed into the $15 \mathrm{~mL}$ APTS dissolved in $584 \mathrm{~mL} \mathrm{DI} \mathrm{H}_{2} \mathrm{O}$ by stirred at $50{ }^{\circ} \mathrm{C}$ for $12 \mathrm{~h}$ to ensure completion of the silanization reaction. The obtained product was $\mathrm{SiO}_{2}-\mathrm{NH}_{2}$ and labelled as $\mathrm{SN}\left(\mathrm{SiO}_{2}\right.$, $10 \%)$.

And then, the silanized silica suspension ( $\mathrm{SN}, 50 \mathrm{~g}$ ) was slowly added into the GO aqueous dispersion and stirred for $2 \mathrm{~h}$. The obtained slurry was dried at $60{ }^{\circ} \mathrm{C}$ for $24 \mathrm{~h}$. The SNfunctionalized $\mathrm{GO}$ ( $\mathrm{GO}$ ratio of $1 \%, 5 \%$, and $10 \%$ ) was designated as $\mathrm{SNGO}_{1}, \mathrm{SNGO}_{5}$, and $\mathrm{SNGO}_{10}$, respectively. Three kinds of $\mathrm{SNGO}\left(\mathrm{SNGO}_{1}, \mathrm{SNGO}_{5}\right.$, and $\left.\mathrm{SNGO}_{10}\right)$ were then pyrolyzed at $800{ }^{\circ} \mathrm{C}$ under nitrogen atmospheres, generating the $\mathrm{SG}_{1}, \mathrm{SG}_{5}$, and $\mathrm{SG}_{10}$, respectively.

2.2.2. Preparation of the SA/SG composites. The composites were prepared using vacuum impregnation method: $3.9 \mathrm{~g}$ support $\left(\mathrm{SG}_{1}, \mathrm{SG}_{5}\right.$, and $\left.\mathrm{SG}_{10}\right)$ and $2.1 \mathrm{~g}$ SA were placed inside a conical flask (the content of SA in the composites was designed as $35 \mathrm{wt} \%$ ), and a device of preventing of backward suction was used to connect the conical flask with vacuum pump. The vacuum of conical flask was evacuated to $-0.1 \mathrm{MPa}$ for $5 \mathrm{~min}$. Then, the conical flask was placed in thermostatical water bath at $95{ }^{\circ} \mathrm{C}$ for $30 \mathrm{~min}$. The vacuum pump was then turned down and allowed the air to enter the flask again, with ultrasonic heating at $80^{\circ} \mathrm{C}$ for $10 \mathrm{~min}$. After cooling, composites were obtained and named as $\mathrm{SA} / \mathrm{SG}_{1}, \mathrm{SA} / \mathrm{SG}_{5}$, and $\mathrm{SA} / \mathrm{SG}_{10}$, respectively.

\subsection{Characterization}

The differential scanning calorimetry (DSC) analysis of SA and SA/SG composites was performed using TA Instruments Q2000 at a heating rate of $5{ }^{\circ} \mathrm{C} \mathrm{min}^{-1}$ from $20{ }^{\circ} \mathrm{C}$ to $80{ }^{\circ} \mathrm{C}$ under a constant stream of nitrogen at the atmospheric pressure. Liquid nitrogen was used for cooling the sample during the freezing period. Thermo-gravimetric analysis (TGA) and differential scanning calorimetry (DSC) analysis were conducted at a heating rate of $10{ }^{\circ} \mathrm{C} \mathrm{min}^{-1}$ up to $550{ }^{\circ} \mathrm{C}$ in nitrogen atmosphere, using $\alpha-\mathrm{Al}_{2} \mathrm{O}_{3}$ crucibles in NETZSCH STA 449F3. X-ray diffraction (XRD) was carried out by using a Rigaku D/max-rA analyzer $(\mathrm{Cu}-\mathrm{K} \alpha)$ under the following conditions: voltage of 40 $\mathrm{kV}$; current of $40 \mathrm{~mA}$; scan range from $5^{\circ}$ to $80^{\circ}$ and step size of $0.02^{\circ}$. The thermal conductivity of the samples at room temperature was measured by means of steady-state heat flow method using a thermal conductivity tester (DRX-II-RW, 

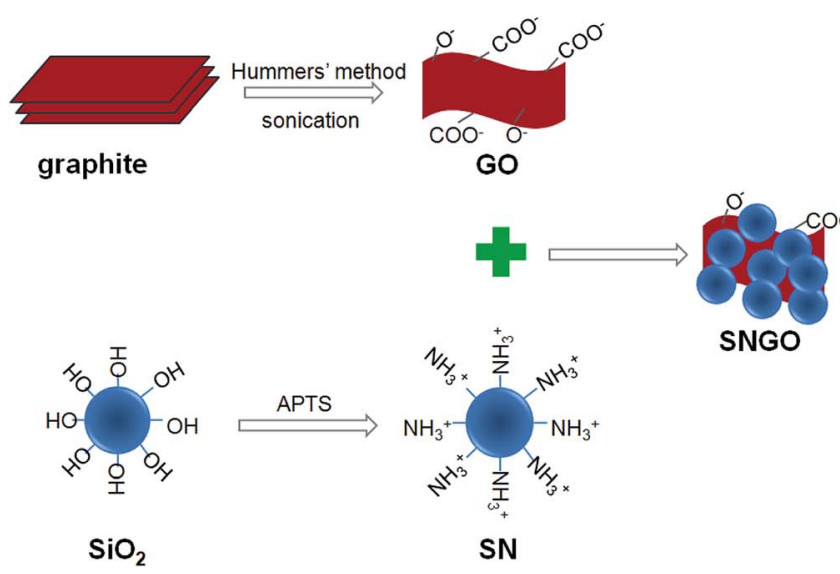
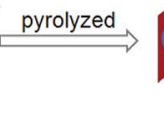

SG
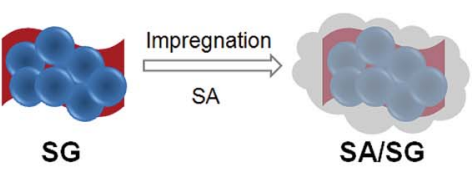

SA/SG

Fig. 1 Schematic illustration of the preparation process of the SG and SA/SG composites.

Xiangtan Huafeng Instrument Manufacturing Co., Ltd., Hunan, China). ${ }^{36}$ The microstructures of the samples were investigated by a JEOL JSM-6360LV scanning electron microscopy (SEM). Fourier transform infrared spectroscopy (FTIR) spectra were recorded by using a Thermo Electron Corporation Nicolet 6700 FTIR spectrometer in the range of $4000-400 \mathrm{~cm}^{-1}$. Nitrogen gas adsorption-desorption isotherms for the SG were measured by an ASAP 2020 surface area and porosimetry system, and the SG samples were outgassed prior to the measurement at $523.15 \mathrm{~K}$ and $10^{-4}$ mbar for $12 \mathrm{~h}$.

\section{Results and discussions}

\subsection{XRD and FTIR characterization for preparing SG}

The XRD patterns of the graphite before and after modified Hummers method were illustrated in Fig. S1. $\dagger$ It is seem that GO showed two diffraction peaks at $2 \theta=10.4^{\circ}$ and $11.3^{\circ}$, indicating the complete exfoliation of the graphite. ${ }^{34}$ The XRD patterns of the $\mathrm{SiO}_{2}$ before and after silanized with APTS were illustrated in Fig. S1, $\uparrow$ suggesting that the $\mathrm{SiO}_{2}$ still maintained amorphous silica. Fig. $\mathrm{S} 2 \uparrow$ showed the XRD patterns of the SNGO before and after pyrolyzed at $800{ }^{\circ} \mathrm{C}$ under nitrogen atmospheres. It indicated that the samples kept the amorphous form after pyrolyzed under nitrogen atmospheres. The silica present amorphous form or crystalline form at different atmospheres. ${ }^{37,38}$ The silica used here pyrolyzed at $800{ }^{\circ} \mathrm{C}$ under nitrogen atmosphere and air atmosphere were amorphous form and crystalline form, respectively (Fig. S3†), and these results were in accord with the References. ${ }^{37,38}$ Fig. S4 $\dagger$ showed the FTIR spectrum of the graphite, $\mathrm{GO}, \mathrm{SiO}_{2}$, and $\mathrm{SN}$. Compared with the FTIR spectrum of graphite, that of GO exhibited the bands at around $3410 \mathrm{~cm}^{-1}, 1726 \mathrm{~cm}^{-1}, 1623 \mathrm{~cm}^{-1}, 1145 \mathrm{~cm}^{-1}$, and 1114 $\mathrm{cm}^{-1}$, which can be attributed to the oxygen containing functional groups on GO. ${ }^{39}$ In the FTIR spectrum for the $\mathrm{SiO}_{2}$ and $\mathrm{SN}$, the weakened band at $1384 \mathrm{~cm}^{-1}$ indicated that the APTS bonded to $\mathrm{SiO}_{2}$. The FTIR spectrum of the SNGO and SG were shown in Fig. S5. $\dagger$ It is seem that the bands at $3450 \mathrm{~cm}^{-1}$ and $1630 \mathrm{~cm}^{-1}$ in the SNGO had disappeared after pyrolyzed (see the FTIR spectrum of SG in Fig. S5 $\dagger$ ), verifying the reduction of GO to $\mathrm{G}$ under nitrogen atmospheres. ${ }^{40}$

\subsection{Crystallization characteristics of the SA/SG composites}

The XRD patterns of the SA/SG composites with different contents of graphene were illustrated in Fig. 2a. The reflections at $2 \theta=21.2^{\circ}$ and $23.5^{\circ}$ were characteristic of the SA (inset of Fig. 2a). After the SA was impregnated into the SG, the characteristic reflections of the SA were observed in the XRD patterns of the SA/SG composites. Comparing the XRD patterns of pure SA (inset of Fig. 2a) and SG (Fig. S2 $\dagger$ ), a new weak peak emerged at $2 \theta=22.6,22.6$, and 23.0 in the $\mathrm{SA} / \mathrm{SG}_{1}, \mathrm{SA} / \mathrm{SG}_{5}$, and $\mathrm{SA} / \mathrm{SG}_{10}$, respectively, should be noticed. These peaks suggested a novel interaction between the SA and the SG matrix, which could had an effect on its phase change process.

\subsection{FTIR analysis of the SA/SG composites}

FTIR spectra of the SA, SG, and SA/SG composites were depicted in Fig. 2b. From the spectra of pure SA, the characteristic vibration peaks of the $\mathrm{SA}$ were at $2920 \mathrm{~cm}^{-1}\left(-\mathrm{CH}_{3}\right.$ group symmetrical stretching), $2850 \mathrm{~cm}^{-1}\left(-\mathrm{CH}_{2}\right.$ group symmetrical stretching), $1704 \mathrm{~cm}^{-1}\left(\mathrm{C}=\mathrm{O}\right.$ stretching), $1465 \mathrm{~cm}^{-1}(-\mathrm{OH}$ bending), $1382 \mathrm{~cm}^{-1}$ (-OH bending), $1113 \mathrm{~cm}^{-1} \quad(\mathrm{C}=\mathrm{O}$ stretching), $723 \mathrm{~cm}^{-1}$ (-OH swinging), and $680 \mathrm{~cm}^{-1}(-\mathrm{OH}$ bending). ${ }^{41,42}$ From the spectra of the $\mathrm{SG}_{1}, \mathrm{SG}_{5}$, and $\mathrm{SG}_{10}$, the characteristic vibration peaks of the SG were at $1096 \mathrm{~cm}^{-1}(\mathrm{Si}-$ O-Si asymmetry stretching and), $804 \mathrm{~cm}^{-1}$ (symmetric stretching mode of the $\mathrm{Si}-\mathrm{O}-\mathrm{Si}$ bond), and $463 \mathrm{~cm}^{-1}$ (Si-O-Si bending). ${ }^{38}$ According to the FTIR spectra of the SA/SG composites, the peak at $804 \mathrm{~cm}^{-1}$ of the SG weakened in the SA/SG composites and the peak at $1096 \mathrm{~cm}^{-1}$ shifted to a higher wavenumber of $1113 \mathrm{~cm}^{-1}$. This phenomenon also suggested a novel interaction between the SA and the SG matrix.

\subsection{Morphological investigation of the SA/SG composites}

The SEM images and EDS patterns of the $\mathrm{SG}_{5}$ and $\mathrm{SA} / \mathrm{SG}_{5}$ were shown in Fig. 3. The irregular particles of $\mathrm{SG}_{5}$ were observed from Fig. 3a and emerged with the size ranges of $0.5-30 \mu \mathrm{m}$. A lot of small particles dispersed around the large particles. The EDS patterns of the $\mathrm{SG}_{5}$ (inset of Fig. 3a) suggested that the graphene and the silica were successfully mixed together and the content of the graphene in the $\mathrm{SG}_{5}$ approached the designed value (5\%). 
a
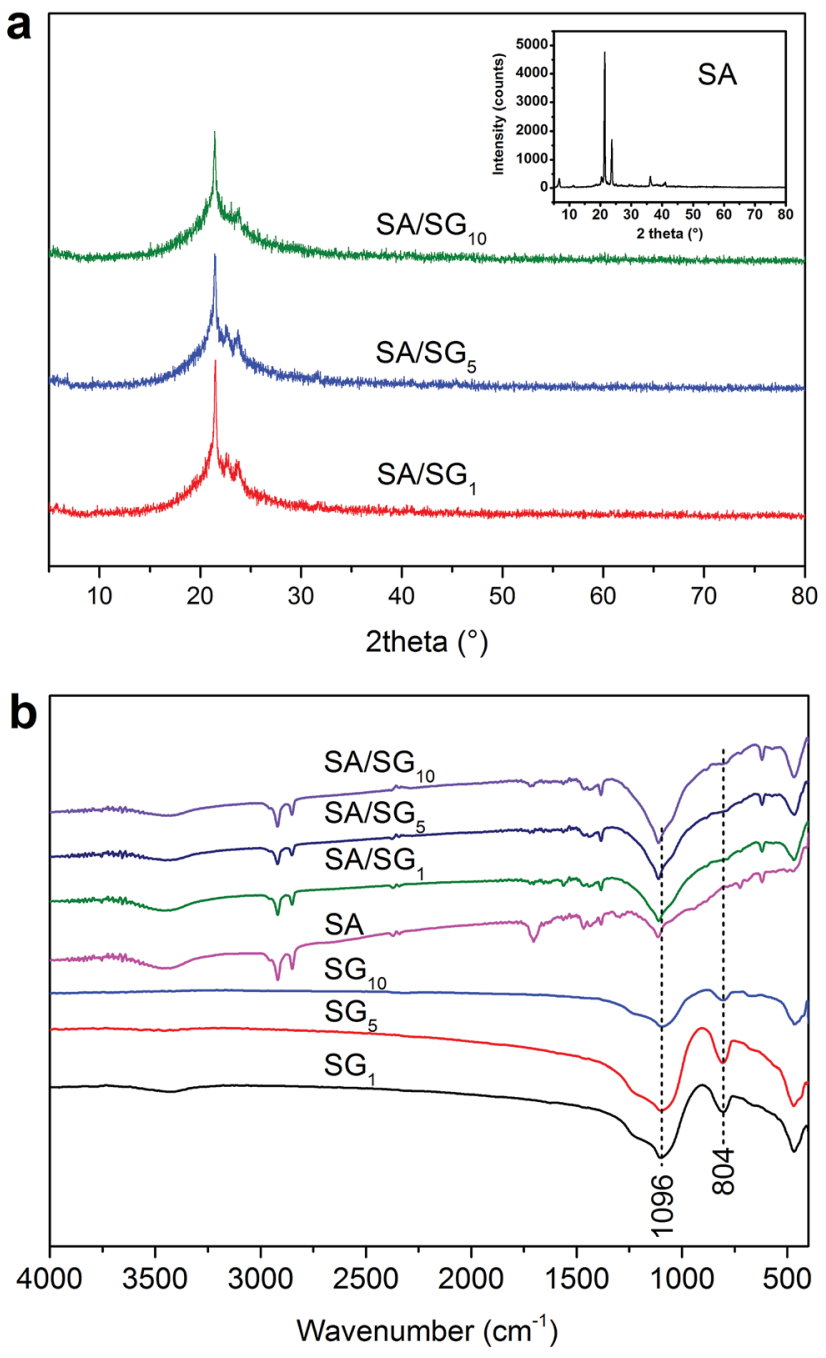

Fig. 2 (a) XRD patterns of the SA/SG composites and (b) FTIR spectra of the samples.

After the impregnation, the sizes of irregular particles were enlarged by introducing the SA and ranged from $5 \mu \mathrm{m}$ to $50 \mu \mathrm{m}$, indicating from SEM images of the $\mathrm{SG}_{5}$ (Fig. 3b). From the EDS patterns of the $\mathrm{SG}_{5}$ (inset of Fig. 3b), the mass ratio of $\mathrm{C}$ element increased due to the added SA and also approached the designed value. By comparing Fig. 3a with $3 \mathrm{~b}$, it can be concluded that the surfaces of $\mathrm{SG}_{5}$ were occupied by $\mathrm{SA}$ in the $\mathrm{SA} / \mathrm{SG}_{5}$, and the $\mathrm{SG}$ particles were surrounded by the SA and formed aggregates. Interestingly, some flakes emerged in the smaller particle of the $\mathrm{SA} / \mathrm{SG}_{5}$ (Fig. 3c) and also in larger particle of the $\mathrm{SA} / \mathrm{SG}_{5}$ (Fig. 3d). It illustrated that the SA was fully adsorbed onto the $\mathrm{SG}_{5}$ and the mass ratio of SA was no overdose.

\subsection{Thermal stability of the SA/SG composites}

For the application of PCMs, thermal stability determines their practical environment and should be thermally stable over its operating temperature range. So, good thermal stability always is a critical parameter for TES applications. TGA is the most commonly used method to characterize the thermal stability of
PCMs. ${ }^{43}$ Fig. 4 illustrated the TGA-DSC curves of the SA and SA/ SG composites. There was a single degradation process for the SA and SA/SG composites due to the decomposition of SA, and no decomposition was observed for the SA/SG composites within $200{ }^{\circ} \mathrm{C}$. In this study, the thermal stability of the SA/SG composites was evaluated with respect to their degradation temperatures $\left(T_{5 \%}\right)$ at which the mass losses were higher than $5 \%$ (Fig. 4a). The SA/SG composites degraded at a high temperature of above $247^{\circ} \mathrm{C}\left(T_{5 \%}\right)$ and evaporated completely at around $500{ }^{\circ} \mathrm{C}$, while for the SA, a low $T_{5 \%}$ at $242.3^{\circ} \mathrm{C}$ was found and evaporated completely at around $350{ }^{\circ} \mathrm{C}$, indicting SA/SG composites had higher thermal stability than pure SA. That is to say, the thermal stability of the SA in the SA/SG composites was enhanced by the SG matrix. With the content of graphene in SG composites increasing, the $T_{5 \%}$ of the SA/SG composites also rose and were $247.5{ }^{\circ} \mathrm{C}, 260.1{ }^{\circ} \mathrm{C}$, and $265.1{ }^{\circ} \mathrm{C}$ for $\mathrm{SA} / \mathrm{SG}_{1}, \mathrm{SA} /$ $\mathrm{SG}_{5}$, and $\mathrm{SA} / \mathrm{SG}_{10}$, respectively. It indicated that the graphene had an advantage for thermal stability of the SA/SG composite. Compared with the $T_{5 \%}$ of pure SA, the $T_{5 \%}$ of the SA/SG $1, \mathrm{SA} /$ $\mathrm{SG}_{5}$, and $\mathrm{SA} / \mathrm{SG}_{10}$ were about $5.2{ }^{\circ} \mathrm{C}, 17.8^{\circ} \mathrm{C}$, and $22.8^{\circ} \mathrm{C}$ higher than that of SA, respectively. Moreover, the degradation temperature of the SA/SG composites were much higher than their phase change temperatures. It can be concluded that the SA/SG composites had good thermal stability in their operating temperature range or above their melting points. From the corresponding DSC curves (Fig. 4b), a endothermic peak at around $321{ }^{\circ} \mathrm{C}$ in the DSC curve of pure SA indicated the SA decomposed. The $\mathrm{SA} / \mathrm{SG}_{1}$ and $\mathrm{SA} / \mathrm{SG}_{5}$ had same tendency in the DSC curves. But, the DSC curve of $\mathrm{SA} / \mathrm{SG}_{10}$ was found to be clearly different from that of the $\mathrm{SA} / \mathrm{SG}_{1}$ and $\mathrm{SA} / \mathrm{SG}_{5}$ : a broad endothermic peak at around $150{ }^{\circ} \mathrm{C}$ appeared in the curve while no evident peak in that of the $\mathrm{SA} / \mathrm{SG}_{1}$ and $\mathrm{SA} / \mathrm{SG}_{5}$ at this temperature interval. This may be related to the interaction between the SA and the SG matrix. Moreover, the exact content of the SA in the SA/SG composites had been confirmed by the TGA. The content of SA in the $\mathrm{SA} / \mathrm{SG}_{1}, \mathrm{SA} / \mathrm{SG}_{5}$, and $\mathrm{SA} / \mathrm{SG}_{10}$ were $34.3 \mathrm{wt} \%, 34.3 \mathrm{wt} \%$, and $34.8 \mathrm{wt} \%$, respectively, which approached the designed value (35 wt $\%)$.

\subsection{Thermal energy storage behaviors and properties of the SA/SG composites}

The thermal energy storage behaviors and properties of the SA and SA/SG composites were determined by DSC thermal analysis (Fig. 5a). The onset temperature of each DSC peak was obtained from the intersection of a line at the point of maximum slope of the leading edge of the DSC peak and the extrapolated baseline on the same side of the peak. ${ }^{44}$ The detailed thermal energy storage properties of the SA and SA/SG composites were given in Table 1 . The curve of pure SA (inset of Fig. 5a) showed a melting temperature $\left(T_{\mathrm{m}}\right)$ at $54.11{ }^{\circ} \mathrm{C}$ in the endothermic curve and a freezing temperature $\left(T_{\mathrm{f}}\right)$ at $53.22^{\circ} \mathrm{C}$ in the exothermic curve. The latent heats of melting $\left(\Delta H_{\mathrm{m}}\right)$ and freezing $\left(\Delta H_{\mathrm{f}}\right)$ of pure SA were $177.3 \mathrm{~J} \mathrm{~g}^{-1}$ and $173.8 \mathrm{~J} \mathrm{~g}^{-1}$, respectively.

The thermal energy storage behaviors are a crucial factor for composite PCMs. Compared with pure SA and the SA/SG 
a

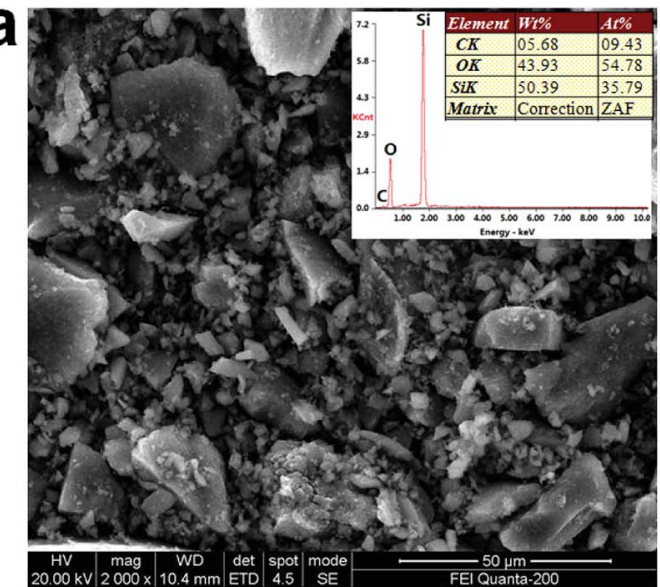

C

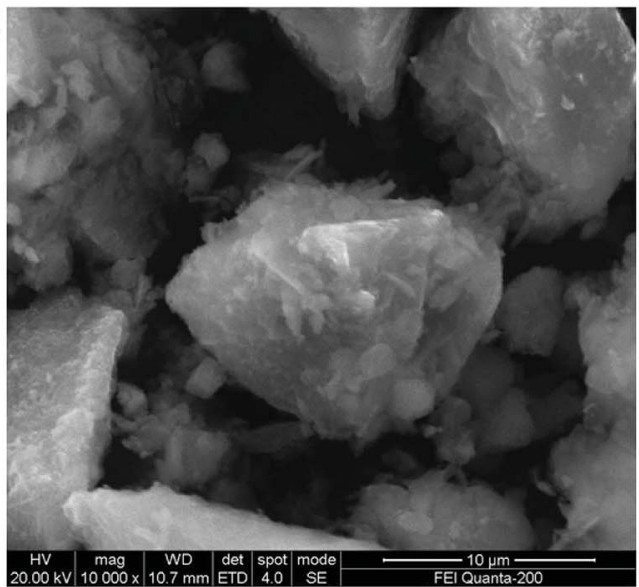

b
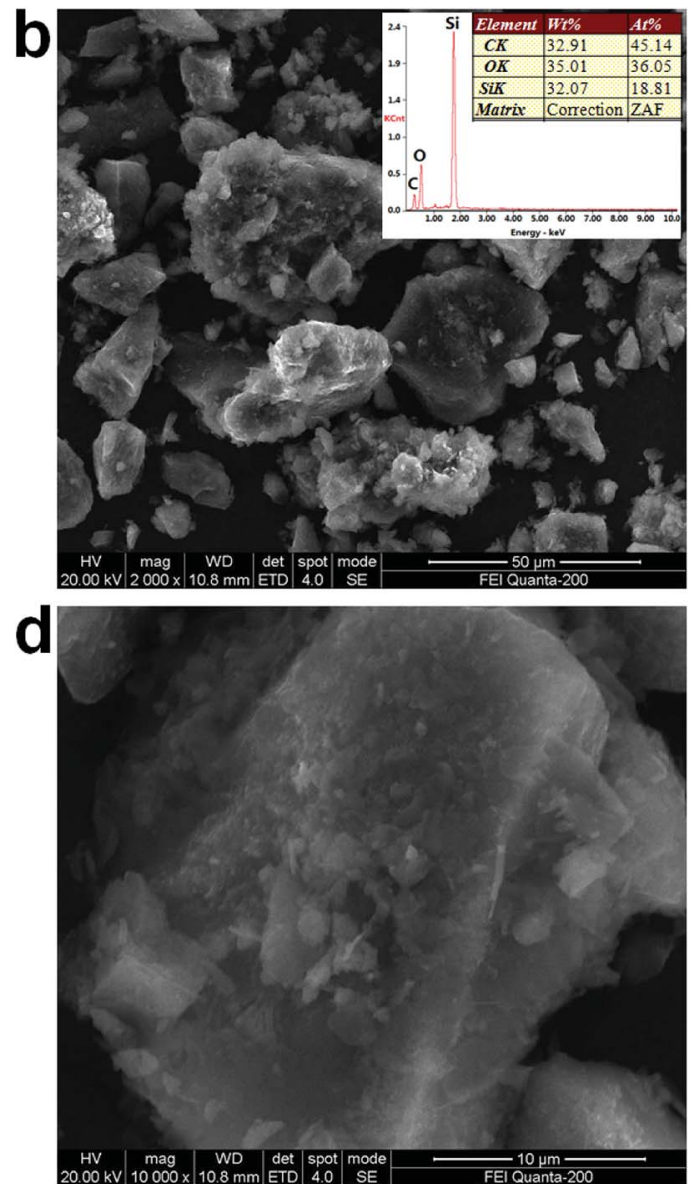

Fig. 3 SEM images and EDS patterns of the (a) $\mathrm{SG}_{5}$ and (b) SA/SG $\mathrm{S}_{5}$; magnified SEM images of (c) smaller particle of the $\mathrm{SA} / \mathrm{SG} \mathrm{G}_{5}$ and (d) larger particle of the $\mathrm{SA} \mathrm{SG}_{5}$.

composites, it was surprising to find that more than one peak in the endothermic or exothermic curves of the composites (Fig. 5a). The thermal characteristics of the composites were very different from that of pure SA (inset of Fig. 5a), indicating a novel interaction between the SA and the SG matrix ${ }^{45}$ which was also reflected in the XRD, FTIR, and TG-DSC results. $\mathrm{SA} / \mathrm{SG}_{1}$ had three phase change processes: the phase changes were at $47.15{ }^{\circ} \mathrm{C}, 52.16{ }^{\circ} \mathrm{C}$, and $54.03{ }^{\circ} \mathrm{C}$ in endothermal curve, respectively; the phase changes were $48.18{ }^{\circ} \mathrm{C}, 52.51{ }^{\circ} \mathrm{C}$, and $54.92^{\circ} \mathrm{C}$ in the exothermal curve, respectively. There was a similar phenomenon in the DSC curve of the $\mathrm{SA}_{/} \mathrm{SG}_{5}$. But the comparison between the $\mathrm{SA} / \mathrm{SG}_{1}$ and the $\mathrm{SA} / \mathrm{SG}_{5}$ indicated a tiny difference: the phase change temperature at $47.15{ }^{\circ} \mathrm{C}, 52.16^{\circ} \mathrm{C}$, and $54.03{ }^{\circ} \mathrm{C}$ in endothermal curve shifted to lower temperatures of $45.55{ }^{\circ} \mathrm{C}, 51.53{ }^{\circ} \mathrm{C}$, and $47.91{ }^{\circ} \mathrm{C}$, respectively (Table 1). Nevertheless, $\mathrm{SA} / \mathrm{SG}_{10}$ had two phase change processes: the phase changes were at $39.03{ }^{\circ} \mathrm{C}$ and $52.58{ }^{\circ} \mathrm{C}$ in endothermal curve, respectively; the phase changes were $39.96{ }^{\circ} \mathrm{C}$ and $50.28{ }^{\circ} \mathrm{C}$ in the exothermal curve, respectively. A large separation of about $10{ }^{\circ} \mathrm{C}$ emerged in the DSC curve of SA/SG 10 and the phase change peaks became more defined. For pure SG, there was no endothermal or exothermal peak in the DSC curves (Fig. S6 $\dagger$ ) in the same temperature range, indicating that SG had no contribution to the phase change peak of the SA/SG composites. From what is discussed above, the thermal energy storage behaviors of the SA were changed by impregnating it into the SG matrix. As further increasing the adding ratio of the graphene in the $\mathrm{SG}$ composites $\left(\mathrm{SG}_{1}, \mathrm{SG}_{5}\right.$, and $\mathrm{SG}_{10}$ ), the thermal energy storage behaviors of the SA/SG composites ( $\mathrm{SA} / \mathrm{SG}_{1}, \mathrm{SA} / \mathrm{SG}_{5}$, and $\mathrm{SA} / \mathrm{SG}_{10}$ ) were dramatically changed.

The latent heats of melting and freezing were $51.35 \mathrm{~J} \mathrm{~g}^{-1}$ and $49.83 \mathrm{~J} \mathrm{~g}^{-1}$ for $\mathrm{SA} / \mathrm{SG}_{1}, 51.32 \mathrm{~J} \mathrm{~g}^{-1}$ and $49.18 \mathrm{~J} \mathrm{~g}^{-1}$ for $\mathrm{SA} / \mathrm{SG}_{5}$, and $37.14 \mathrm{~J} \mathrm{~g}^{-1}$ and $33.87 \mathrm{~J} \mathrm{~g}^{-1}$ for $\mathrm{SA} / \mathrm{SG}_{10}$, respectively, which were less than their corresponding theoretical values (Table 1). The decrease in the latent heats of the composites was not only attributable to the lower fraction of SA within the composites, but could also be related to the crystallinity of the SA in the composites. Crystallization of the SA in the composites may be inhibited by interactions between the SA and the supports, which would also reduce the latent heats of the composites. ${ }^{46}$ The crystallinity of the SA $\left(F_{\mathrm{c}}\right)$ in the composite was calculated by: $:^{46-49}$

$$
F_{\mathrm{c}}=\frac{\Delta H_{\text {composite }}}{\Delta H_{\text {pure }} \beta} \times 100 \%
$$

where $\Delta H_{\text {composite }}$ and $\Delta H_{\text {pure }}$ were the latent heats of the composites and pure SA, respectively, and $\beta$ represented the loading of SA in the composites. The crystallinity of the SA in the 

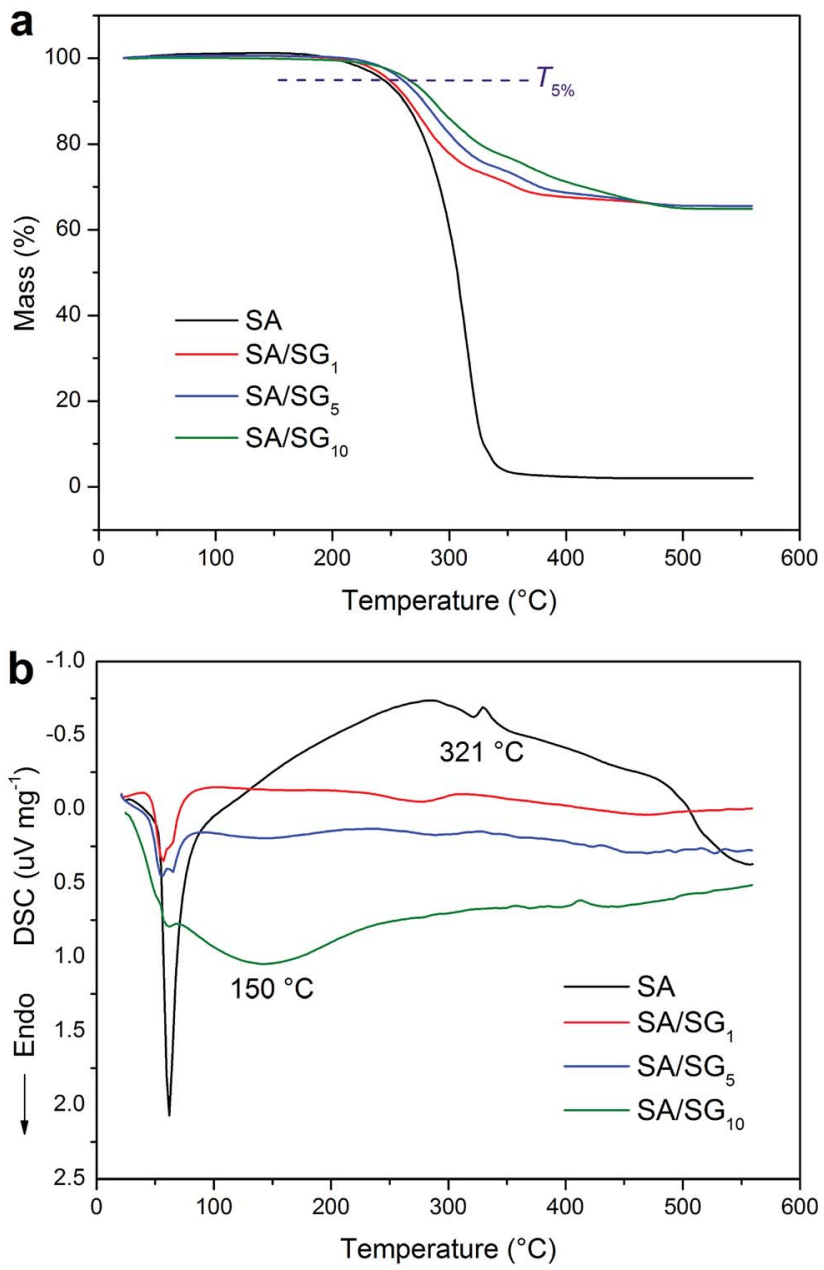

Fig. 4 TGA (a) - DSC (b) of the $S A, S A / S G_{1}, S A / S G_{5}$, and $S A / S G_{10}$.

$\mathrm{SA} / \mathrm{SG}_{1}(84.44 \%)$ was close to that in the $\mathrm{SA} / \mathrm{SG}_{5}(84.39 \%)$, and they were clearly higher than that in the $\mathrm{SA} / \mathrm{SG}_{10}(60.19 \%)$. According to our previous research, ${ }^{13,49}$ it meant that more confined SA (disordered) in the $\mathrm{SA} / \mathrm{SG}_{10}$ composite, comparing with more free $\mathrm{SA}$ (ordered) in the $\mathrm{SA} / \mathrm{SG}_{1}$ and $\mathrm{SA} / \mathrm{SG}_{5}$ composites. That is to say, with increasing the adding ratio of the graphene in the SG composites, more SA were confined by the SG. The confined SA cannot crystallize and will not work for thermal energy storage. ${ }^{49}$ The effective energy stored per unit mass of the SA $\left(E_{\text {ef }}\right)$ was used to evaluate the effectiveness of the $\mathrm{SA}$ in different composites (Table 1 ). The SA in the $\mathrm{SA} / \mathrm{SG}_{1}$ and in the $\mathrm{SA} / \mathrm{SG}_{5}$ had a adjacent $E_{\mathrm{ef}}\left(\sim 150 \mathrm{~J} \mathrm{~g}^{-1}\right)$ which higher than that of the $\mathrm{SA} / \mathrm{SG}_{10}\left(106.7 \mathrm{~J} \mathrm{~g}^{-1}\right)$.

Furthermore, the thermal energy storage properties of the SA/SG composites with different contents of SA were investigated by increasing SA dosage (designed as $40 \%$ and $45 \%$ ) for the $\mathrm{SA} / \mathrm{SG}_{5}$ composite. Fig. $5 \mathrm{~b}$ demonstrated the DSC curves of the $\mathrm{SA}^{+} / \mathrm{SG}_{5}$ and $\mathrm{SA}^{++} / \mathrm{SG}_{5}$, and the content of $\mathrm{SA}$ in the $\mathrm{SA}^{+} / \mathrm{SG}_{5}$ and $\mathrm{SA}^{++} / \mathrm{SG}_{5}$ were determined as $39.5 \%$ and $44.8 \%$ by TGA (inset of Fig. $5 \mathrm{~b}$ ). The detailed thermal energy storage properties of the $\mathrm{SA}^{+} / \mathrm{SG}_{5}$ and $\mathrm{SA}^{++} / \mathrm{SG}_{5}$ were given in Table $\mathrm{S} 1 . \dagger$ Increasing the content of SA to $39.5 \%$, the DSC curve of the $\mathrm{SA}^{+} / \mathrm{SG}_{5}$ reduced to two phase change processes (Fig. $5 \mathrm{~b}$ ). Compared to
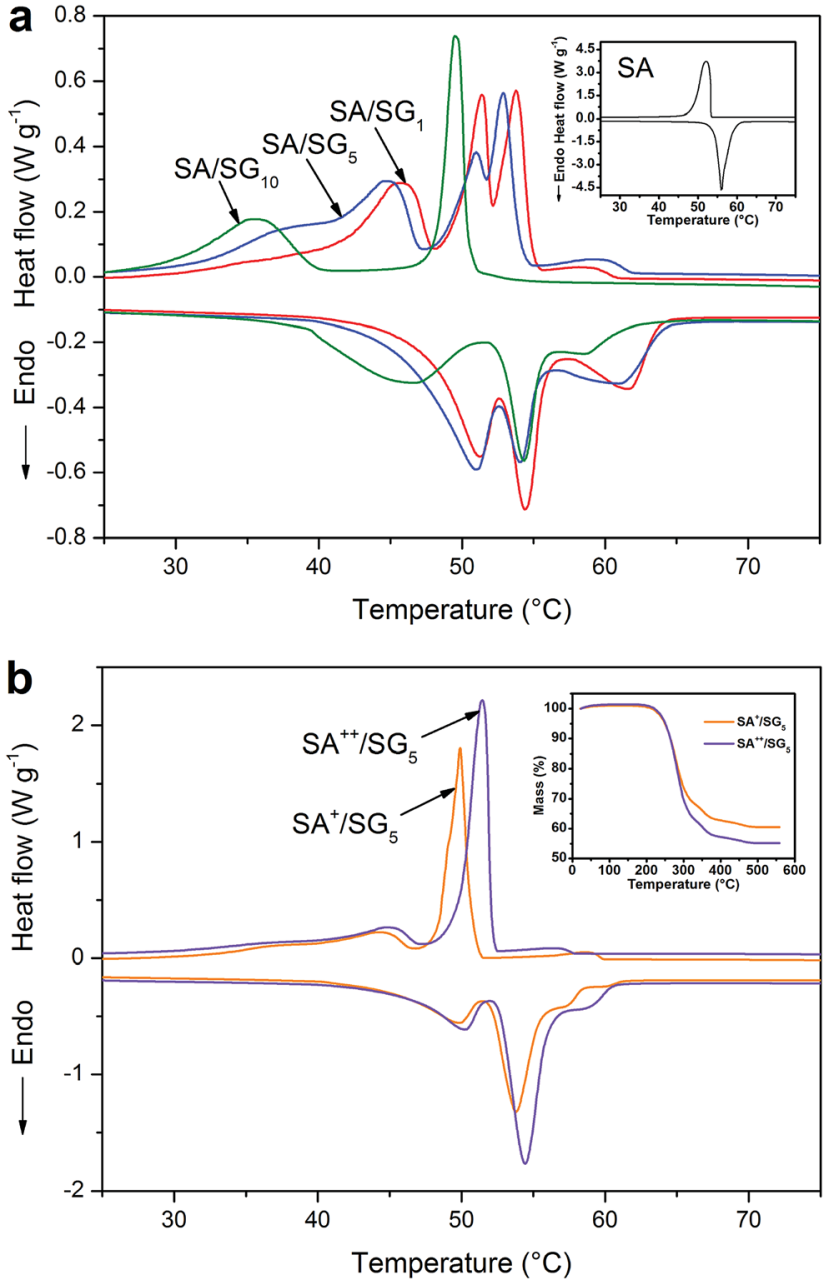

Fig. 5 (a) DSC curves of the (a) $\mathrm{SA}$, (b) $\mathrm{SA} / \mathrm{SG}_{1}$, (c) $\mathrm{SA} / \mathrm{SG}_{5}$, and (d) $\mathrm{SA} /$ $\mathrm{SG}_{10}$; (b) DSC curves and TG (inset) of the $\mathrm{SA}^{+} / \mathrm{SG}_{5}$ and $\mathrm{SA}^{++} / \mathrm{SG}_{5}$.

the $\mathrm{SA} / \mathrm{SG}_{5}$, the phase change peaks of $\mathrm{SA}^{+} / \mathrm{SG}_{5}$ at high temperatures became a single peak and enhancive. As further increasing the content of SA to $44.8 \%$, the phase change peaks at low temperatures shifted to higher temperature zone. Meanwhile, the phase change peaks at high temperatures became more enhancive, which manifested that the incremental SA in the $\mathrm{SA}^{++} / \mathrm{SG}_{5}$ had mainly contributed to the phase change enthalpy occurring at the high temperatures. With increasing the content of SA, the crystallinities of SA in composites were enhanced to $86.25 \%$ and $88.44 \%$ for $\mathrm{SA}^{+} / \mathrm{SG}_{5}$ and $\mathrm{SA}^{++} / \mathrm{SG}_{5}$, respectively.

The phenomenon: (a) more than one endothermal or exothermal peak in the DSC curves of SA/SG composites; (b) the $E_{\text {ef }}$ decreased while increasing the adding ratio of graphene in the $\mathrm{SA} / \mathrm{SG}_{10}$ indicated an interesting question between the SA and the SG matrix. This interesting question may be connected to the special pore structure of the SG matrix on the basis of our previous research. ${ }^{13,49}$ To unlock this interesting question and further clarify this hypothesis, the pore structure of the SG matrix were depicted in Fig. 6, and the specific surface areas and porous properties of them were listed in Table 2 . The specific 
Table 1 Thermal properties of the SA and SA/SG composites ${ }^{a}$

\begin{tabular}{lllllllll}
\hline Samples & $\begin{array}{l}\text { Loadage } \\
(\beta, \mathrm{wt} \%)\end{array}$ & $\begin{array}{l}\text { Melting } \\
\text { temperature } \\
\left(T_{\mathrm{m}},{ }^{\circ} \mathrm{C}\right)\end{array}$ & $\begin{array}{l}\text { Freezing } \\
\text { temperature } \\
\left(T_{\mathrm{f}},{ }^{\circ} \mathrm{C}\right)\end{array}$ & $\begin{array}{l}\text { Latent heat } \\
\text { of melting } \\
\left(\Delta H_{\mathrm{m}}, \mathrm{J} \mathrm{g}^{-1}\right)\end{array}$ & $\begin{array}{l}\text { Latent heat } \\
\text { of freezing } \\
\left(\Delta H_{\mathrm{f}}, \mathrm{J} \mathrm{g}^{-1}\right)\end{array}$ & $\begin{array}{l}\text { Theoretic } \\
\text { values of } \Delta H_{\mathrm{m}} \\
\left(\Delta H_{\mathrm{th}}, \mathrm{J} \mathrm{g}^{-1}\right)\end{array}$ & $\begin{array}{l}\text { Crystallinity } \\
\text { of SA }\left(F_{\mathrm{c}}, \%\right)\end{array}$ & $\begin{array}{l}\text { Efficient } \\
\text { energy per unit } \\
\mathrm{mass} \text { of SA }\left(E_{\mathrm{ef}}, \mathrm{J} \mathrm{g}^{-1}\right)\end{array}$ \\
\hline $\mathrm{SA}$ & 100 & 54.11 & 53.22 & 177.3 & 173.8 & - & 100 & - \\
$\mathrm{SA} / \mathrm{SG}_{1}$ & 34.3 & $47.15 / 52.16 / 54.03$ & $48.18 / 52.51 / 54.92$ & 51.35 & 49.83 & 60.81 & 84.44 & 149.7 \\
$\mathrm{SA}_{\mathrm{SG}}$ & 34.3 & $45.55 / 51.53 / 47.91$ & $47.24 / 53.14 / 54.03$ & 51.32 & 49.18 & 60.81 & 84.39 & 149.6 \\
$\mathrm{SA} / \mathrm{SG}_{10}$ & 34.8 & $39.03 / 52.58$ & $39.96 / 50.28$ & 37.14 & 33.87 & 61.70 & 60.19 & 106.7
\end{tabular}

${ }^{a}$ Note: $\Delta H_{\text {th }}=\Delta H_{\text {pure }} \times \beta ; E_{\text {ef }}=\Delta H_{\text {pure }} \times F_{\text {c }}$.
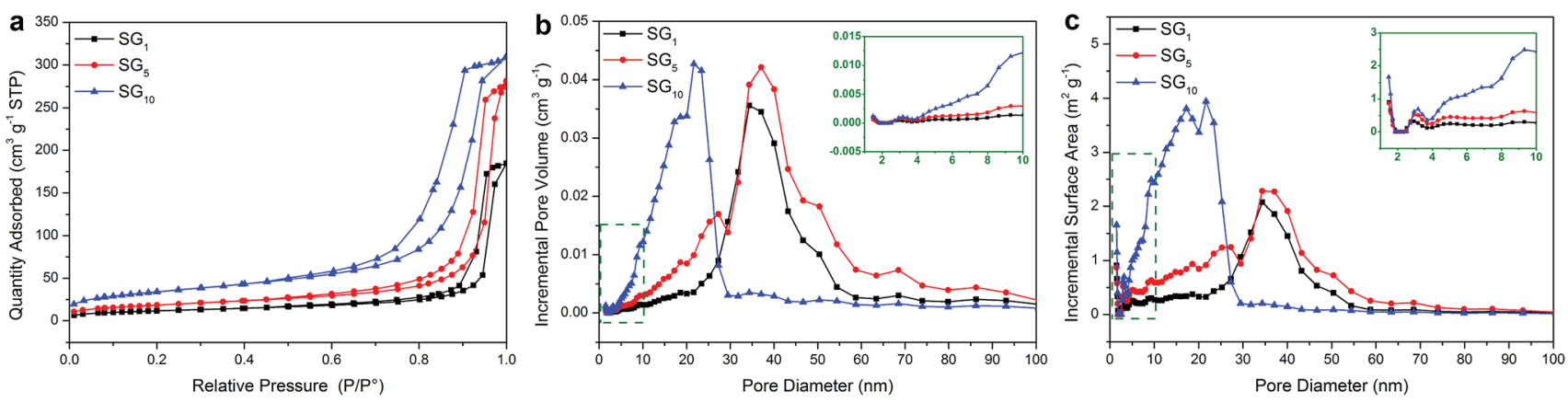

Fig. 6 (a) Nitrogen adsorption-desorption isotherms of the SG, and BJH pore size distribution for (b) incremental pore volume and (c) incremental surface area.

surface areas of the $\mathrm{SG}_{1}, \mathrm{SG}_{5}$, and $\mathrm{SG}_{10}$ were calculated to be $41.29 \mathrm{~m}^{2} \mathrm{~g}^{-1}, 65.29 \mathrm{~m}^{2} \mathrm{~g}^{-1}$, and $120.27 \mathrm{~m}^{2} \mathrm{~g}^{-1}$, respectively. The results also exhibited that the adsorption cumulative volume of pores and surface area of pores of $\mathrm{SG}_{10}$ were $0.49 \mathrm{~cm}^{3} \mathrm{~g}^{-1}$ and $136.38 \mathrm{~m}^{2} \mathrm{~g}^{-1}$, respectively, which larger than that of the $\mathrm{SG}_{1}$ and $\mathrm{SG}_{5}$. With increasing the adding ratio of graphene in the SG composites, the adsorption average pore widths of the SG decreased and were $26.16 \mathrm{~nm}, 24.00 \mathrm{~nm}$, and $14.50 \mathrm{~nm}$ for $\mathrm{SG}_{1}$, $\mathrm{SG}_{5}$, and $\mathrm{SG}_{10}$, respectively. Compared with the pore size distributions in incremental pore volume and in incremental surface area of the $\mathrm{SG}_{1}$ and $\mathrm{SG}_{5}$, the $\mathrm{SG}_{10}$ had significantly different pore size distributions while the $\mathrm{SG}_{1}$ and $\mathrm{SG}_{5}$ presented approximately status (Fig. $6 \mathrm{~b}$ and c). The most pore volume and surface area of the $\mathrm{SG}_{10}$ distributed in the size range of 5 to $30 \mathrm{~nm}$, while that of the $\mathrm{SG}_{1}$ and $\mathrm{SG}_{5}$ appeared in larger size range $(20-60 \mathrm{~nm})$. Observing the pore diameters from $5 \mathrm{~nm}$ to $30 \mathrm{~nm}$, the $\mathrm{SG}_{5}$ had slightly more pore volume and surface area than that of the $\mathrm{SG}_{1}$, resulting in a tiny difference in the DSC curves (Fig. 5a). After introduced to the supporting matrix, the SA molecules (long hydrocarbon chains) were adsorbed in different size pore. Previous researches have been testified that the phase change temperatures of organic phase change materials decrease as the supporting spaces become narrower. ${ }^{45,50,51}$ Thus, the SA molecules adsorbed in serial narrower pore exhibited different lower temperature of phase change just like $\mathrm{SA} / \mathrm{SG}_{1}$ and $\mathrm{SA} / \mathrm{SG}_{5}$ (Fig. 5a). With increasing the adding ratio of graphene in the SG composites, the more pore volume distributed in the small size, the more SA was supported in these pore-size ranges. It resulted in the phase change temperatures further shifted to lower temperature due to the rotation of the hydrocarbon chains require more low thermal energy in this condition..$^{\mathbf{5 0} 51}$ Compared with the pore size distribution in incremental pore volume of the $\mathrm{SG}_{1}$ and $\mathrm{SG}_{5}(20-$ $60 \mathrm{~nm}$ and $40 \mathrm{~nm}$ ), the $\mathrm{SG}_{10}$ had a smaller and concentrated size range (5-30 $\mathrm{nm}$ and $25 \mathrm{~nm}$ ), generating a defined phase change peaks occurring $10{ }^{\circ} \mathrm{C}$ lower. Also, the interaction (including surface tension forces and capillary forces) occurred between the SA and the SG matrix would be strong enough to disturb its phase change process when the pore can confine the crystallization of the PCM. ${ }^{49,52}$ Colligated the above discussions, the

Table 2 Specific surface areas and porous properties of the SG

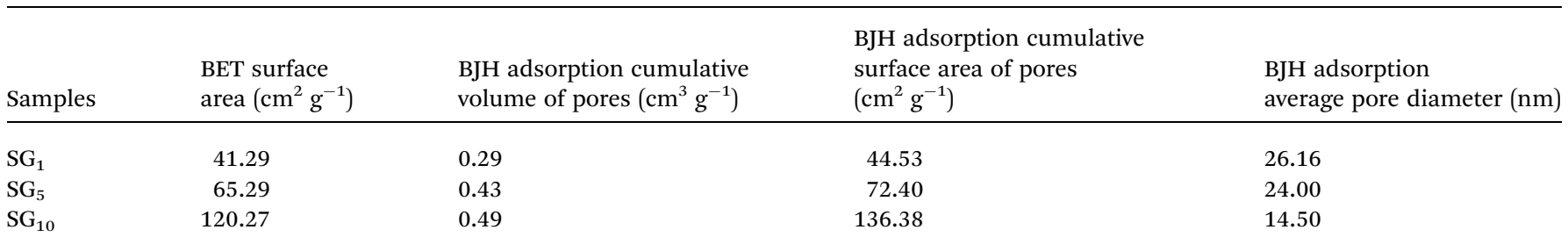


different pore structure of the SG matrix could be a reason to more than one endothermal or exothermal peak in the DSC curves of the SA/SG composites. From the inset of Fig. $6 \mathrm{~b}$ and c, the $\mathrm{SG}_{10}$ had larger pore volume and surface area than that of the $\mathrm{SG}_{1}$ and $\mathrm{SG}_{5}$ in the size range of $1-10 \mathrm{~nm}$, signifying more $\mathrm{SA}$ hydrocarbon chains were confined in the $\mathrm{SA} / \mathrm{SG}_{10}$. Moreover, the interaction between the SA and the SG matrix of capillary and surface tension forces could affect the crystallization of the $\mathrm{SA},{ }^{49}$ the larger capillary and surface tension forces between the $\mathrm{SA}$ and the $\mathrm{SG}_{10}$ was contributed to the larger BET surface area of the $\mathrm{SG}_{10}$ (Table 2). And then the interaction between the SA and the SG matrix in the $\mathrm{SA} / \mathrm{SG}_{10}$ is more than that in the $\mathrm{SA} / \mathrm{SG}_{1}$ and $\mathrm{SA} / \mathrm{SG}_{5}$. This is consistent with the observation from the thermal stability results (Fig. $4 \mathrm{~b}$ ): the $\mathrm{SA} / \mathrm{SG}_{10}$ need greater energy to out of the shackles of the surface of $\mathrm{SG}_{10}$ and then a broad endothermic peak at around $150{ }^{\circ} \mathrm{C}$ appeared while no

Table 3 Thermal conductivities of the SA and SA/SG composites

\begin{tabular}{llllll}
\hline Samples & $\mathrm{SA}$ & $\mathrm{SA} / \mathrm{SG}_{1}$ & $\mathrm{SA} / \mathrm{SG}_{5}$ & $\mathrm{SA} / \mathrm{SG}_{10}$ & $\mathrm{SA} / \mathrm{SiO}_{2}$ \\
\hline$\lambda\left(\mathrm{W} \mathrm{m}^{-1} \mathrm{~K}^{-1}\right)$ & 0.26 & 0.90 & 1.05 & 1.12 & 0.58
\end{tabular}

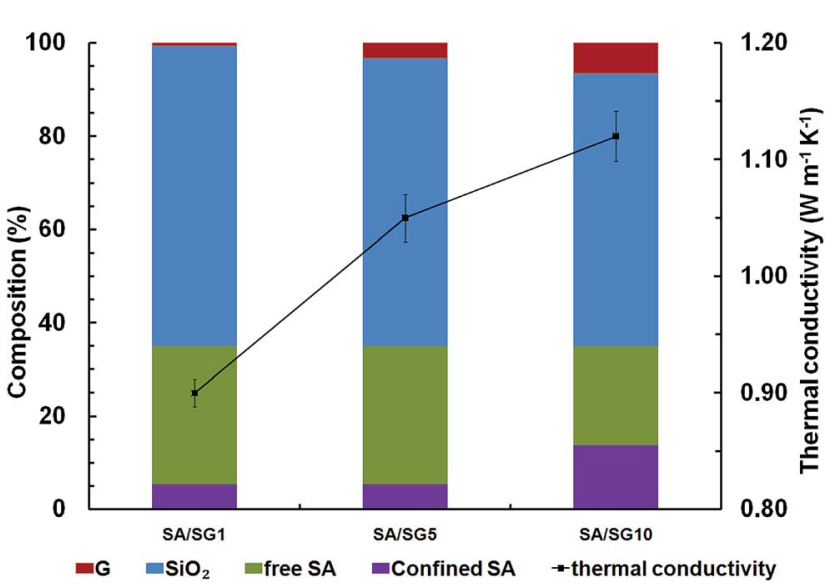

Fig. 7 The compositions and thermal conductivities of the SA/SG composites. evident peak in that of the $\mathrm{SA} / \mathrm{SG}_{1}$ and $\mathrm{SA} / \mathrm{SG}_{5}$ at this temperature interval. These then dramatically decreased the crystallinity of the SA in the $\mathrm{SA} / \mathrm{SG}_{10}$ composite, comparing with that in the $\mathrm{SA} / \mathrm{SG}_{1}$ and $\mathrm{SA} / \mathrm{SG}_{5}$ composites. As mentioned above, the confined SA cannot crystallize and will not work for thermal energy storage. So, the $E_{\text {ef }}$ decreased while increasing the adding ratio of graphene in the $\mathrm{SA} / \mathrm{SG}_{10}$.

\subsection{Thermal conductivities of the SA/SG composites}

The thermal conductivity values were $0.26,0.90,1.05$, and $1.12 \mathrm{~W} \mathrm{~m} \mathrm{~m}^{-1} \mathrm{~K}^{-1}$ for the $\mathrm{SA}, \mathrm{SA} / \mathrm{SG}_{1}, \mathrm{SA} / \mathrm{SG}_{5}$, and $\mathrm{SA} / \mathrm{SG}_{10}$, respectively (Table 3 ). For comparison, the silica without decorated by graphene was prepared and used to support the SA by the same process described in experimental, labeling as $\mathrm{SA} / \mathrm{SiO}_{2}$ with a thermal conductivity of $0.58 \mathrm{~W} \mathrm{~m}^{-1} \mathrm{~K}^{-1}$. The comparison between the thermal conductivities of pure SA and the $\mathrm{SA} / \mathrm{SiO}_{2}$ demonstrated that $\mathrm{SiO}_{2}$ substrate could improve the thermal conductivity of pure SA by $123 \%$. In order to further enhance the thermal conductivities of the composites, the $\mathrm{SiO}_{2}$ substrate was decorated by graphene. The enhancements in the thermal conductivity compared with that of $\mathrm{SA} / \mathrm{SiO}_{2}$ were $55 \%, 81 \%$, and $93 \%$ for the $\mathrm{SA} / \mathrm{SG}_{1}, \mathrm{SA} / \mathrm{SG}_{5}$, and $\mathrm{SA} / \mathrm{SG}_{10}$, respectively. The enhancements in the thermal conductivity compared with that of SA were $246 \%, 304 \%$, and $331 \%$ for the $\mathrm{SA} / \mathrm{SG}_{1}, \mathrm{SA} / \mathrm{SG}_{5}$, and $\mathrm{SA} / \mathrm{SG}_{10}$, respectively. From the $\mathrm{SA} / \mathrm{SG}_{1}$ to the $\mathrm{SA} / \mathrm{SG}_{5}$, the thermal conductivity of composites was enhanced by $17 \%$; from the $\mathrm{SA} / \mathrm{SG}_{5}$ to the $\mathrm{SA} / \mathrm{SG}_{10}$, the thermal conductivity of composites was only enhanced by $7 \%$. These illustrated that with increasing the graphene ratio, thermal conductivity enhancing ability of graphene decreased, and the reason was explained in the following paragraph.

Thermal conductivities of SA/SG composites were governed by phonon propagation, because the composites were blends of the nonmetal (SG) and the organic materials (SA) (Fig. 1). ${ }^{53}$ For a nonmetallic composite, the ordered or disordered crystals, grain boundary, and interfaces significantly affected the phonon transport. ${ }^{54-57}$ In particular, the disorder in crystals usually interferes with heat conduction in most materials; thus disordered component tend to have lower thermal conductivity because of strong phonon scattering. ${ }^{58}$ The components of the

Table 4 Comparison of the thermal properties of the as-synthesized composite with the reported materials

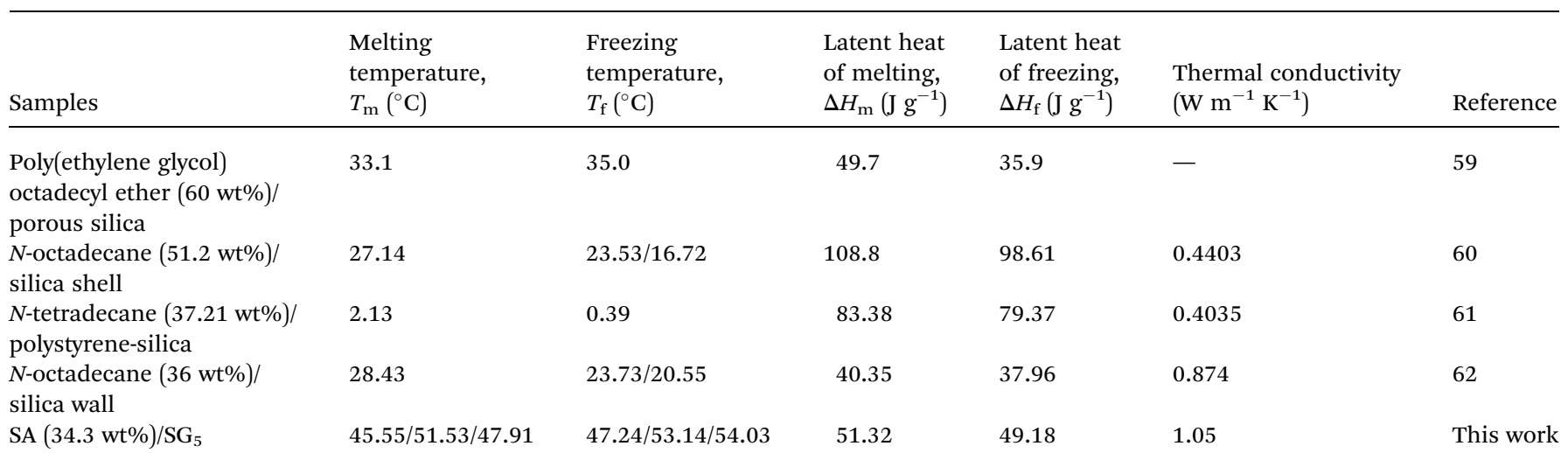


SA/SG composites were exhibited in Fig. 7. All the SA/SG composites had a almost same SA loadage ( $35 \mathrm{wt} \%)$, but showed a different proportion of the confined SA. The SA/SG had a very similar proportion of the confined SA to that of the $\mathrm{SA} / \mathrm{SG}_{1}$, and the $\mathrm{SA}$ in the $\mathrm{SA} / \mathrm{SG}_{1}$ and in the $\mathrm{SA} / \mathrm{SG}_{5}$ had a comparative thermal conductivity. The thermal conductivity of the $\mathrm{SA} / \mathrm{SG}_{5}$ was obviously (17\%) enhanced with increasing the content of graphene (G, $0.65 \%$ to $3.25 \%)$. But with increasing the content of $\mathrm{G}$, the confined $\mathrm{SA}$ in the $\mathrm{SA} / \mathrm{SG}_{10}$ reached $13.93 \%$, there are more disordered SA in the composites. The SA in the $\mathrm{SA} / \mathrm{SG}_{10}$ had a lower thermal conductivity due to stronger phonon scattering. It deservedly affected the thermal conductivity of the SA/SG $\mathrm{SG}_{10}$. Therefore, the thermal conductivity of the $\mathrm{SA} / \mathrm{SG}_{10}$ were smaller (7\%) enhanced with increasing the content of $\mathrm{G}(3.25 \%$ to $6.50 \%)$. Thus, thermal conductivity enhancing ability of $\mathrm{G}$ in the $\mathrm{SA} / \mathrm{SG}_{10}$ decreased.

In addition, Table 4 showed the comparison of the latent heats and the thermal conductivities of the prepared composite PCMs with that of silica-based composite PCMs in the literature, ${ }^{59-62}$ the $\mathrm{SA} / \mathrm{SG}_{5}$ composite showed some obvious advantages over the reported materials: added phase change temperatures, considerable latent heat capacities with less PCMs dosage, and higher thermal conductivity (more than 1.0 $\mathrm{W} \mathrm{m} \mathrm{m}^{-1} \mathrm{~K}^{-1}$ ), which broadens its wide application for thermal energy storage. It is remarkably noted that the prepared $\mathrm{SA} / \mathrm{SG}_{5}$ composite has potential for application in the thermal energy storage, especially in the thermal gradient using.

\section{Conclusions}

Novel thermal energy storage materials $\left(\mathrm{SA} / \mathrm{SG}_{1}, \mathrm{SA} / \mathrm{SG}_{5}\right.$, and SA/ $\mathrm{SG}_{10}$ ) were synthesized from graphene-decorated silica (SG) and stearic acid (SA) by vacuum impregnation method. The structure and thermal energy storage performances of the SA/SG composites were in detail investigated by XRD, FTIR, SEMEDS, TG-DSC, DSC, BET, and thermal conductivity. The SA/ $\mathrm{SG}_{1}, \mathrm{SA} / \mathrm{SG}_{5}$, and $\mathrm{SA} / \mathrm{SG}_{10}$ composites have good thermal stability and the thermal degradation temperature increased by $5.2{ }^{\circ} \mathrm{C}, 17.8^{\circ} \mathrm{C}$, and $22.8^{\circ} \mathrm{C}$ against pure SA. It is of interest that the thermal energy storage behaviors of the SA/SG composites were dramatically changed along with different contents of graphene, presenting more than one endothermal or exothermal peaks in the DSC curves while pure SA only one of that. The $\mathrm{SA}$ in the $\mathrm{SA} / \mathrm{SG}_{1}$ and in the $\mathrm{SA} / \mathrm{SG}_{5}$ showed greater effective energy storage per unit mass $\left(E_{\mathrm{ef}}, \sim 150 \mathrm{~J} \mathrm{~g}^{-1}\right)$ than that of $\mathrm{SA}$ in the $\mathrm{SA} / \mathrm{SG}_{10}$. These thermal energy storage behaviors and properties were illuminated to be related to the special pore structure of SG matrix by nitrogen gas adsorption-desorption isotherms. Decorating silica by graphene was beneficial to the enhancement in thermal conductivity of the SA/SG composite, and $55 \%, 81 \%$, and $93 \%$ higher than that of $\mathrm{SA} / \mathrm{SiO}_{2}$ (without decorated by graphene), respectively; and 246\%, 304\%, and $331 \%$ higher than that of pure SA, for $\mathrm{SA} / \mathrm{SG}_{1}, \mathrm{SA} / \mathrm{SG}_{5}$, and SA/ $\mathrm{SG}_{10}$, respectively. The $\mathrm{SA} / \mathrm{SG}_{5}$ has potential for application in thermal energy storage, especially in the thermal gradient using due to both the considerable $E_{\text {ef }}$ and the high thermal conductivity of $1.05 \mathrm{~W} \mathrm{~m}^{-1} \mathrm{~K}^{-1}$.

\section{Acknowledgements}

This work was supported by the National Natural Science Foundation of China (51504041), the Natural Science Foundation of Hunan Province (2016JJ3009), the Scientific Research Fund of Hunan Provincial Education Department (15K007), and the Key Laboratory of Renewable Energy Electric-Technology of Hunan Province (2015ZNDL006 and 2017ZNDL009).

\section{Notes and references}

1 M. Aneke and M. Wang, Appl. Energy, 2016, 179, 350-377.

2 J. Niu, A. Kushima, M. Li, Z. Wang, W. Li, C. Wang and J. Li, J. Mater. Chem. A, 2014, 2, 19788-19796.

3 C. Li, B. Xie, J. Chen, J. He and Z. He, RSC Adv., 2017, 7, 13184-13190.

4 J. Niu, A. Kushima, X. Qian, L. Qi, K. Xiang, Y.-M. Chiang and J. Li, Nano Lett., 2014, 14, 4005-4010.

5 X. Wu, Y. Li, C. Li, Z. He, Y. Xiang, L. Xiong, D. Chen, Y. Yu, K. Sun, Z. He and P. Chen, J. Power Sources, 2015, 300, 453-459. 6 L. Liu, D. Su, Y. Tang and G. Fang, Renewable Sustainable Energy Rev., 2016, 62, 305-317.

7 Y. Xu, Q. Ren, Z.-J. Zheng and Y.-L. He, Appl. Energy, 2017, 193, 84-95.

8 H. Zhang, J. Baeyens, G. Cáceres, J. Degrève and Y. Lv, Prog. Energy Combust. Sci., 2016, 53, 1-40.

9 X. Gao, Y. Yuan, X. Cao, H. Wu and X. Zhao, Process Saf. Environ. Prot., 2017, 107, 438-453.

10 Y. Yuan, X. Gao, H. Wu, Z. Zhang, X. Cao, L. Sun and N. Yu, Energy, 2017, 119, 817-833.

11 F. Tang, L. Liu, G. Alva, Y. Jia and G. Fang, Sol. Energy Mater. Sol. Cells, 2017, 160, 1-6.

12 A. Arteconi, N. J. Hewitt and F. Polonara, Appl. Energy, 2012, 93, 371-389.

13 C. Li, L. Fu, J. Ouyang and H. Yang, Sci. Rep., 2013, 3, 1908.

14 M. M. Kenisarin and K. M. Kenisarina, Renewable Sustainable Energy Rev., 2012, 16, 1999-2040.

15 M. Zhou, T. Lin, F. Huang, Y. Zhong, Z. Wang, Y. Tang, H. Bi, D. Wan and J. Lin, Adv. Funct. Mater., 2013, 23, 2263-2269.

16 Y. Wang, B. Tang and S. Zhang, Adv. Funct. Mater., 2013, 23, 4354-4360.

17 Y. Zhang, X. Zheng, H. Wang and Q. Du, J. Mater. Chem. A, 2014, 2, 5304.

18 P. Zhang, X. Xiao and Z. W. Ma, Appl. Energy, 2016, 165, 472510.

19 S. F. Ahmed, M. Khalid, W. Rashmi, A. Chan and K. Shahbaz, Renewable Sustainable Energy Rev., 2017, 67, 450-460.

20 Y. Yuan, N. Zhang, W. Tao, X. Cao and Y. He, Renewable Sustainable Energy Rev., 2014, 29, 482-498.

21 Y. Yuan, T. Li, N. Zhang, X. Cao and X. Yang, J. Therm. Anal. Calorim., 2016, 124, 881-888.

22 X. Min, M. Fang, Z. Huang, Y. g. Liu, Y. Huang, R. Wen, T. Qian and X. Wu, Sci. Rep., 2015, 5, 12964.

23 G. Fang, H. Li, Z. Chen and X. Liu, J. Hazard. Mater., 2010, 181, 1004-1009.

24 G. Fang, H. Li and X. Liu, Mater. Chem. Phys., 2010, 122, 533536. 
25 O. Chung, S.-G. Jeong, S. Yu and S. Kim, Energ. Build., 2014, 70, 180-185.

26 Y. Wang, T. D. Xia, H. Zheng and H. X. Feng, Energ. Build., 2011, 43, 2365-2370.

27 S.-G. Jeong, J. Jeon, J. Cha, J. Kim and S. Kim, Energ. Build., 2013, 62, 190-195.

28 S. Song, L. Dong, Z. Qu, J. Ren and C. Xiong, Appl. Therm. Eng., 2014, 70, 546-551.

29 C. Liu, C. Wang, Y. Li and Z. Rao, RSC Adv., 2017, 7, 72387249.

30 H. Zhang, X. Wang and D. Wu, J. Colloid Interface Sci., 2010, 343, 246-255.

31 D.-G. Kang, M. Park, D.-Y. Kim, M. Goh, N. Kim and K.-U. Jeong, ACS Appl. Mater. Interfaces, 2016, 8, 3049230501.

32 A. I. Fernandez, M. Martínez, M. Segarra, I. Martorell and L. F. Cabeza, Sol. Energy Mater. Sol. Cells, 2010, 94, 17231729.

33 G.-Q. Qi, C.-L. Liang, R.-Y. Bao, Z.-Y. Liu, W. Yang, B.-H. Xie and M.-B. Yang, Sol. Energy Mater. Sol. Cells, 2014, 123, 171177.

34 Z. B. Lei, L. Lu and X. S. Zhao, Energy Environ. Sci., 2012, 5, 6391-6399.

35 L. L. Zhang, S. Zhao, X. N. Tian and X. S. Zhao, Langmuir, 2010, 26, 17624-17628.

36 J.-L. Zeng, S.-H. Zheng, S.-B. Yu, F.-R. Zhu, J. Gan, L. Zhu, Z.-L. Xiao, X.-Y. Zhu, Z. Zhu, L.-X. Sun and Z. Cao, Appl. Energy, 2014, 115, 603-609.

37 X.-G. Chen, S.-S. Lv, P.-P. Zhang, L. Zhang and Y. Ye, J. Therm. Anal. Calorim., 2011, 104, 1055-1062.

38 M. M. Haslinawati, K. A. Matori, Z. A. Wahab, H. A. A. Sidek and A. T. Zainal, Int. J. Basic Appl. Sci., 2009, 9, 22-25.

39 Y. Huang and S. F. Y. Li, J. Electroanal. Chem., 2013, 690, 8.

40 M. Sun, X. Ma, J. Wang, W. Wang, Q. Wu, C. Wang and Z. Wang, J. Sep. Sci., 2013, 36, 1478-1485.

41 G. Fang, H. Li, Z. Chen and X. Liu, Energy, 2010, 35, 46224626.

42 M. Ferreira, K. Wohnrath, A. Riul, J. A. Giacometti and O. N. Oliveira, J. Phys. Chem. B, 2002, 106, 7272-7277.
43 A. Karaipekli and A. Sarı, Sol. Energy Mater. Sol. Cells, 2016, 149, 19-28.

44 S. Karaman, A. Karaipekli, A. Sarı and A. Biçer, Sol. Energy Mater. Sol. Cells, 2011, 95, 1647-1653.

45 B. Li, T. Liu, L. Hu, Y. Wang and S. Nie, Chem. Eng. J., 2013, 215-216, 819-826.

46 C. Wang, L. Feng, W. Li, J. Zheng, W. Tian and X. Li, Sol. Energy Mater. Sol. Cells, 2012, 105, 21-26.

47 C. Wang, L. Feng, H. Yang, G. Xin, W. Li, J. Zheng, W. Tian and X. Li, Phys. Chem. Chem. Phys., 2012, 14, 13233-13238.

48 Q. Cao and P. Liu, Eur. Polym. J., 2006, 42, 2931-2939.

49 C. Li, L. Fu, J. Ouyang, A. Tang and H. Yang, Appl. Clay Sci., 2015, 115, 212-220.

50 T. Uemura, N. Yanai, S. Watanabe, H. Tanaka, R. Numaguchi, M. T. Miyahara, Y. Ohta, M. Nagaoka and S. Kitagawa, Nat. Commun., 2010, 1, 83.

51 X. Huang, W. Xia and R. Zou, J. Mater. Chem. A, 2014, 2, 19963-19968.

52 Q. Shen, S. Liu, J. Ouyang and H. Yang, RSC Adv., 2016, 6, 112493-112501.

53 C. Li, J. Ouyang and H. Yang, Phys. Chem. Miner., 2013, 40, 681-689.

54 C. Poulier, D. S. Smith and J. Absi, J. Eur. Ceram. Soc., 2007, 27, 475-478.

55 R. M. Costescu, D. G. Cahill, F. H. Fabreguette, Z. A. Sechrist and S. M. George, Science, 2004, 303, 989-990.

56 L. Xie, X. Huang, K. Yang, S. Li and P. Jiang, J. Mater. Chem. A, 2014, 2, 5244.

57 X. Lu, D. T. Morelli, Y. Xia, F. Zhou, V. Ozolins, H. Chi, X. Zhou and C. Uher, Adv. Energy Mater., 2013, 3, 342-348.

58 K. E. Goodson, Science, 2007, 315, 342-343.

59 L. Zhang, H. Shi, W. Li, X. Han and X. Zhang, Thermochim. Acta, 2013, 570, 1-7.

60 S. Liang, Q. Li, Y. Zhu, K. Chen, C. Tian, J. Wang and R. Bai, Energy, 2015, 93, 1684-1692.

61 W. Fu, X. Liang, H. Xie, S. Wang, X. Gao, Z. Zhang and Y. Fang, Energ. Build., 2017, 136, 26-32.

62 F. He, X. Wang and D. Wu, Energy, 2014, 67, 223-233. 